\title{
Carbonate cements in contemporaneous beachrocks, Jaguaribe beach, Itamaracá island, northeastern Brazil: petrographic, geochemical and isotopic aspects
}

\author{
NÚBIA C. GUERRA ${ }^{1}$, CHANG H. KIANG ${ }^{2}$ and ALCIDES N. SIAL ${ }^{1}$ \\ ${ }^{1}$ NEG-LABISE, Departamento de Geologia, UFPE, Cx. Postal 7852, 50670-000 Recife, PE, Brasil \\ ${ }^{2}$ Instituto de Geociências e Ciências Exatas, Departamento de Geologia Aplicada \\ Cx. Postal 178, UNESP, 13506-900 Rio Claro, Brasil
}

Manuscript received on January 26, 2004; accepted for publication on August 20, 2004; contributed by ALCIDES N. SIAL*

\begin{abstract}
Holocene beachrocks of the Jaguaribe beach, State of Pernambuco, northeastern Brazil, consist of horizontal, cemented layers approximately $40 \mathrm{~cm}$ thick. The cement shows three textural varieties: (a) calciferous, surrounding siliciclastic grains, (b) micritic, with an acicular fringe; and (c) cryptocrystalline calcite in pores. Early cementation took place at the water table below beach ridges, where geochemical, hydrodynamic and, perhaps, also microbiological conditions favored rapid precipitation of aragonite and/or high-Mg calcite. $\delta^{13} \mathrm{C}$ values range from -1.8 to $+1.5 \%$ for dissolved carbonate in interstitial water and from +0.2 to $+2.1 \%$ for bioclastic components. $\delta^{18} \mathrm{O}$ values range from -2.8 to $+0.5 \%$ for seawater, freshwater and interstitial water. $\delta^{13} \mathrm{C}$ values and diagenetic features suggest that cementation occurred in meteoric-vadose and/or marine-phreatic water by loss of $\mathrm{CO}_{2}$ during evaporation of the interstitial water. Locally, superimposed low$\mathrm{Mg}$ calcite cements point to subsequent freshwater influence. Total-rock cement composition of vertically stacked beachrock beds at the Jaguaribe beach shows that the highest beachrock bed is older than the one (of same petrographic composition) situated at the current groundwater level. This implies a downward progression of cementation, which probably followed the sea-level fall after a local high stand.
\end{abstract}

Key words: beachrocks, early diagenesis, $\mathrm{O}$ and $\mathrm{C}$ isotopes, Holocene.

\section{INTRODUCTION}

Beachrocks are a common feature along the northeastern coastline of Brazil and have demanded a number of studies because of their role in the interpretation of coastal dynamics. Generally they are found parallel to the coastline as narrow, linear ridges (two or more) separated from each other by sand and/or mud depressions. They consist of sandy deposits, cemented by carbonate and of vari-

\footnotetext{
* Member Academia Brasileira de Ciências Correspondence to: Núbia Chaves Guerra

E-mail: nschaves@ufpe.br
}

able length and extent, regarded to represent ancient coastline. The beachrocks are considered as a "roof ridge" of sandstone and younger beachrocks, representing carbonate precipitation (a common feature of tropical beaches) during the last 20 years, have also been identified on the basis of low degrees of diagenesis, organic activity, and human artifacts (Chaves et al. 1995, Chaves and Sial 1999, Chaves 1996, 2000).

In the studied area (Fig. 1), Jaguaribe beach, situated to the north of Recife city, close to the Itamaracá Island, Pernambuco, beachrocks occur in the 


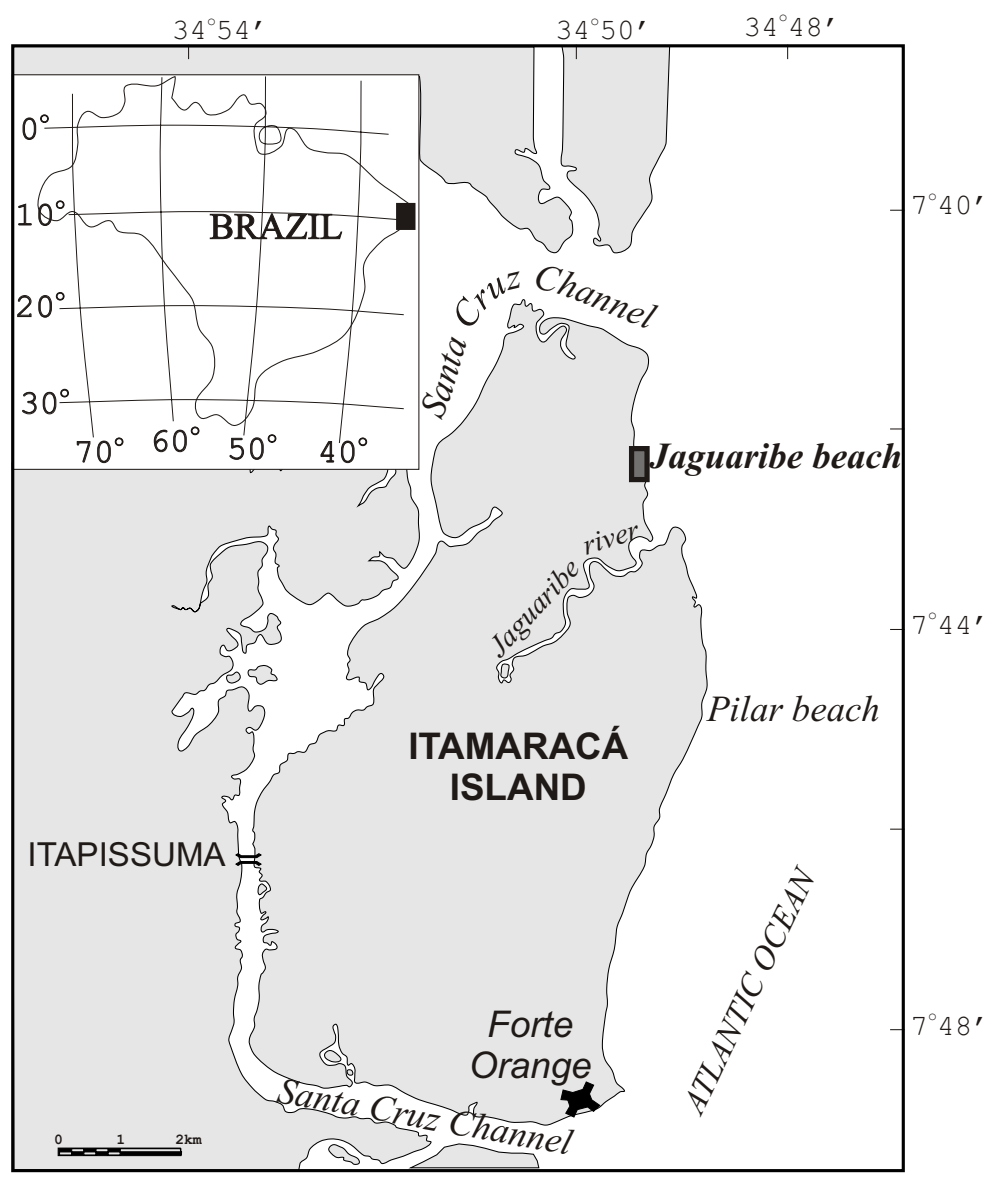

Fig. 1 - Location of the study area at the Jaguaribe beach (Itamaracá island), Pernambuco State, Brazil.

shallow subtidal zone, and are very good examples of early beachrocks. This locality was chosen for detailed study because factors that control the distribution and rate of formation of these cemented zones are important in understanding early carbonate diagenesis. The coastal erosion locally excavates these beachrock beds, and slabs from them accumulate on the beach. Trenches and pits have been dug to follow beachrocks under beach.

The aim of this study is to illustrate the complexity of beachrock cementation and to discuss its relation to sea level, and to synthesize their sedimentological and geochemical characteristics in order to model their depositional environment. The conclusions derived here have been substantiated by stable-isotope geochemistry.

\section{FACIES AND STRATIGRAPHY}

Beach sediments at the studied localities are composed mainly of quartz sands that also contain shells of bivalves and gastropods, foraminifera, and fragments of calcareous algae (Halimeda and Lithothamnium). Coarse- and fine-grained sand layers alternate to form beach lamination dipping slightly seaward. Coarse-grained layers usually are rich in bioclasts; and the predominating fine-grained layers contain mainly opaque minerals. Keystone vugs occur locally and indicate the upper beach facies.

The beach deposits overly a medium-grained facies composed of sands and some bioclasts. Some bioclasts are also found reworked in the beach facies. Roots rarely penetrate sediments below the 


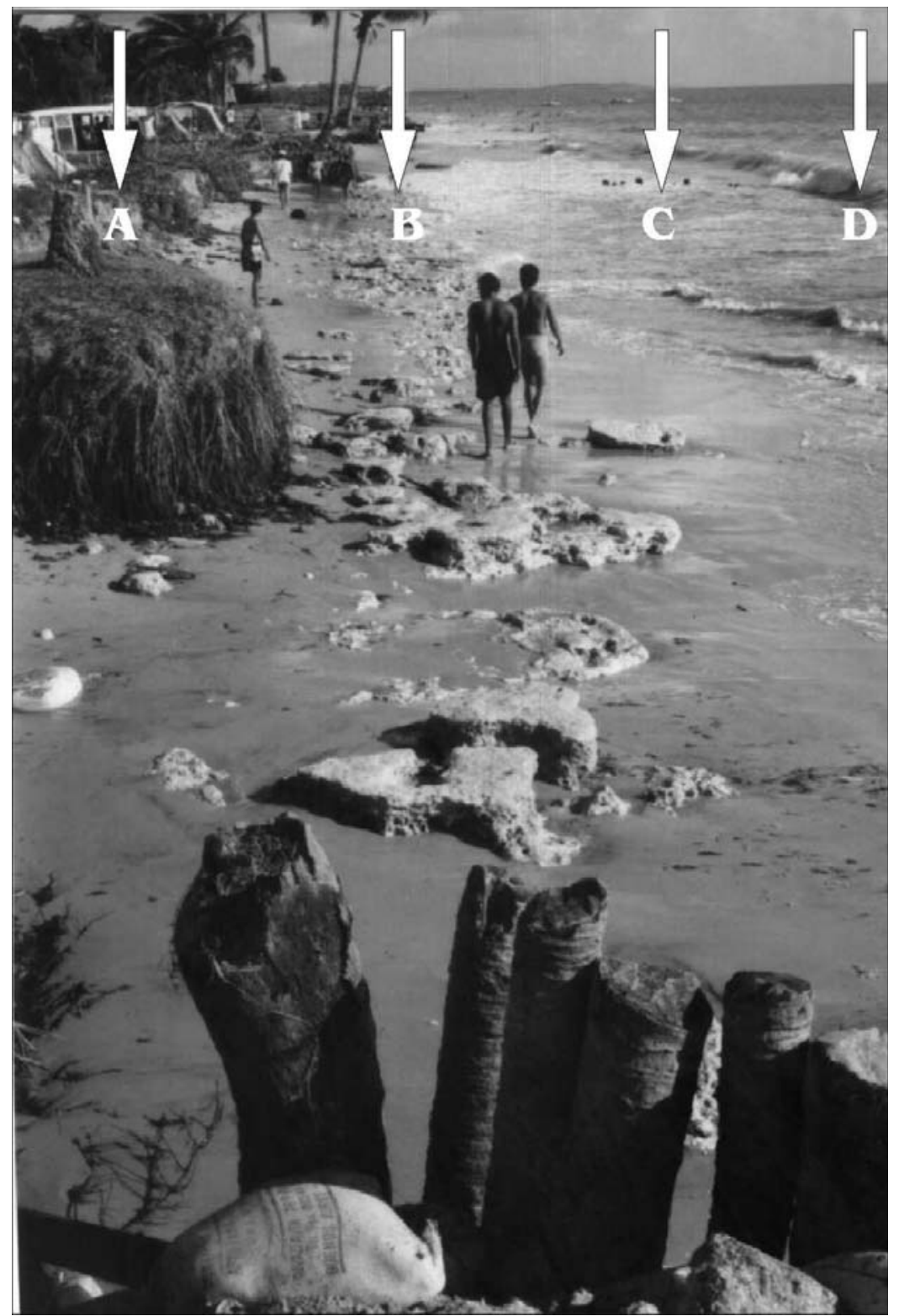

Fig. 2 - Location of the four boreholes made at the Jaguaribe beach (Itamaracá island) to collect water, cement and bioclastic fragments for chemical analyses (Chaves 2000). People are walking on contemporaneous beachrocks, in this photograph.

vegetated beach. This facies succession implies a progradation of terraces over beach deposits.

Cemented beds occur exclusively in beach facies. The highest beachrock bed has been found (Fig. 2) about $40 \mathrm{~cm}$ above the beach face corresponding to low tide while the lowest cemented lay- ers are situated at the water-influenced area. Beachrocks contains $60-80 \%$ quartz grains, up to $10 \%$ bioclastic fragments, and 2-10\% (locally up to 20\%) cement. Porosity is around $45 \%$.

At the studied locality, incipient beachrocks are still found inland some $50 \mathrm{~m}$ from the beach, about 
$40 \mathrm{~cm}$ above the beach face. The beachrocks beds are $15-20 \mathrm{~cm}$ thick, some are continuous and can be followed over tens of meters along the beach where erosion has exposed them; others consist of isolated nodules (Fig. 2).

The surface of the cemented beds is usually slightly undulated and smooth and the lower surface can be very irregular and bumpy. Up to six vertically stacked beachrock levels have been observed, separated from each other by loose sands (Fig. 2). Apart from the cements, the petrographic composition of beachrocks beds and encasing, non-consolidated beach sediments is the same. The primary sedimentary structures (beach lamination, keystone vugs, root traces) are preserved in the beachrocks.

\section{CARBONATE CEMENTATION}

The most common cement in the studied beachrock consists of calcite (determination of mineralogy by EDAX and Feigl's solution). Crystals usually are very small, but may locally reach $0.1 \mathrm{~mm}$ in length. They are very elongate and pointed or display broader, lath-like shapes.

Aragonite typically occurs as acicular crystals forming fringes that are normally oriented to the grain surfaces (Chaves 2000; Fig. 3A,B). In many cases the cement fringe is isopachous, i.e. of equal thickness, indicating marine phreatic precipitation where pores were constantly water-filled. Asymmetric cement fringes and thicker underside of grains, concentrated at grain contacts (Chaves 2000; Fig. 3C,D), are recorded in some beachrocks, and indicate precipitation in the marine vadose zone (e.g. Taylor and Illing 1969).

High- and low-Mg calcite usually forms micritic cement coating grains or filling pores (Chaves 2000; Fig. 3E,F). Micritization of grains is common in the beachrocks. If the meteoric groundwater is high in the backshore area, then low-Mg calcite cements may be precipitated in beachrocks in the upper intertidal zone.

Aragonite platelets occur locally and the ara- gonite crystals commonly form isopachous rims around the grains, thus implying cementation in water-filled pores of a marine-phreatic diagenetic environment (Longman 1980). In many cases, a black layer covers the grain surfaces and forms the base of the aragonite cement. Such layers have been described from various other beachrocks (e.g. Davies and Kinsey 1973, Strasser and Davaud 1986). Davies and Kinsey (1973) suggested that they originated from organic mucus in which micritic carbonate was precipitated and trapped, and which then served as nucleation site for the aragonite crystals.

Marine-phreatic aragonite cements are found in all studied samples, except in those of trench. Some samples contain high-Mg calcite $(35-40 \mathrm{~mol} \%$ $\mathrm{MgCO}_{3}$ ) displaying scalenohedral crystal forms. High-Mg calcite occurs together with aragonite, either growing between the needles and platelets, or replacing them laterally. The magnesium-rich calcite cements display an isopachous disposition and indicate a marine-phreatic environment (Longman 1980). They occur in outcrop and pit, but are not associated with a particular level of beachrock.

Micritic cements (aragonite and/or high-Mg calcite) form meniscus bridges linking the particles together (thus indicating the vadose zone; Longman 1980), or fill the pores completely.

Calcified organic filaments are rarely present and suggest participation of algae and/or fungi in the consolidation of the beachrock. Micrite cements are locally associated with aragonite or calcite crystals. Micritic cementation occurs in several samples and are the dominating types, and beachrock of hole 1 is cemented entirely by micrite cement.

Several samples show large crystals of low-Mg calcite invading and growing over pre-existing aragonite and/or high-Mg calcite cements. They formed in a freshwater diagenetic environment and are limited to beachrock beds above the water table or exposed on the beach, where rainwater could percolate. Locally, the cement covers organic filaments.

Rapid cementation was probably favored at the vadose/phreatic interface, i.e. at the continental wa- 

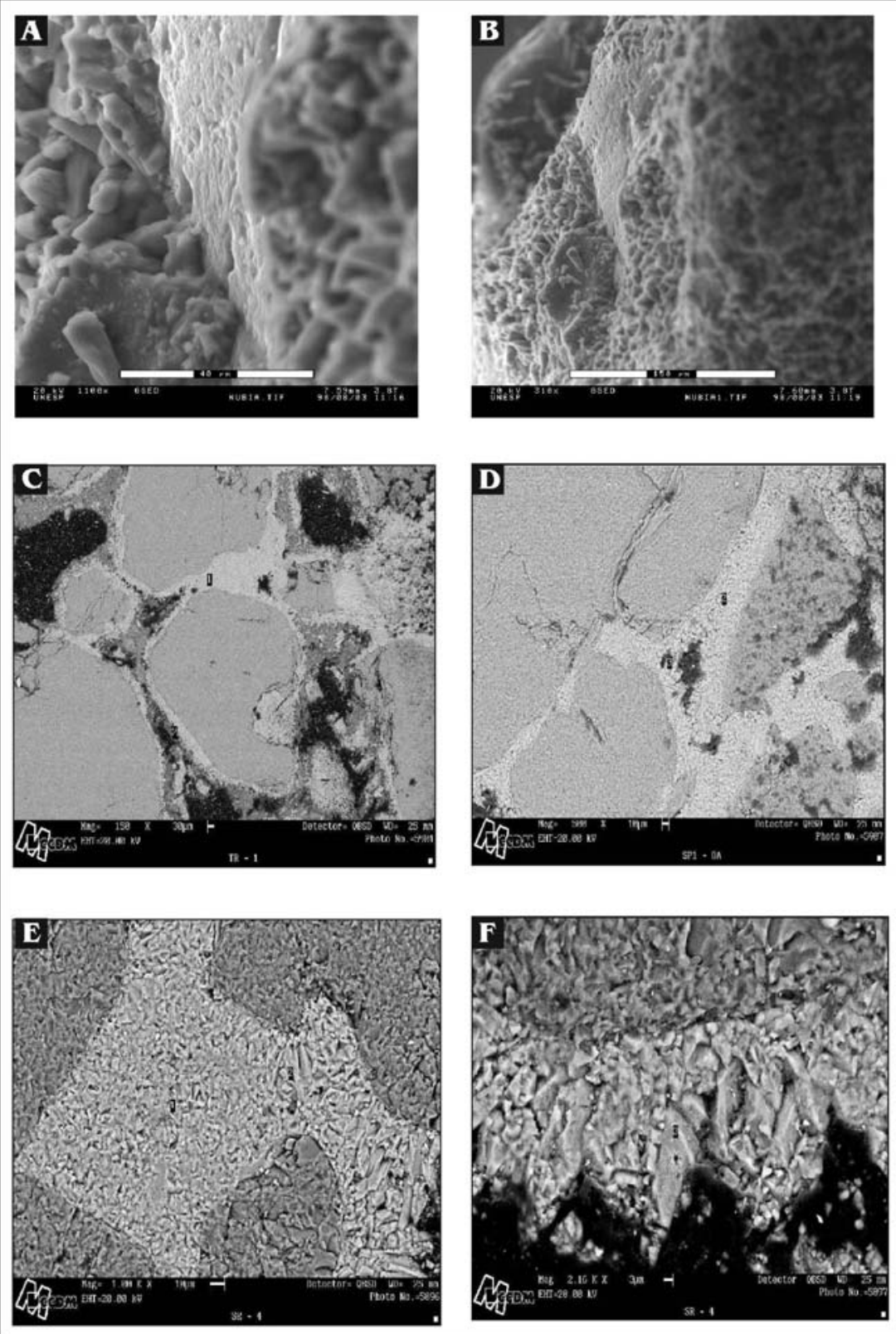

Fig. 3 -Acicular aragonite crystals (A, B); asymmetric fringes of calcite and aragonite (C, D); high- and low-Mg calcite, in micritic and fringe forms (respectively E and F).

ter. There, carbonate precipitation may be stimulated by evaporation of interstitial water (Taylor and Illing 1969) and/or $\mathrm{CO}_{2}$ degassing (Hanor 1978). Water percolation, and thus tidal pumping, may enhance supply of ions. It has been shown by Given and Wilkinson (1985) that percolation rate influ- ences mineralogy and crystal morphology of the precipitated carbonate cements. Good permeability of the well-washed beach sands also explains why cementation occurs preferentially there. Mixing of marine and fresh water at the water table can equally lead to cementation. Furthermore, the metabolic ac- 
tivity of bacteria, algae and fungi living in the sediment may influence $\mathrm{pH}$ and Eh conditions, and certain organic substances can selectively precipitate aragonite or calcite (Kitano and Hood 1965).

Minor and trace elements (Table I) in beachrocks cements demonstrate that, in the case of Jaguaribe beach, the relatively low strontium contents (1.69 to $1.77 \mathrm{ppm}$ ) and iron in the beachrock cements could (at least partly) be explained by assimilation of these elements by algae and bacteria. Low Sr indicates that calcite cement was precipitated initially as aragonite in meteoric water environment according to Baker et al. (1982). Adsorption of organic matter on carbonate crystal surfaces (Suess 1970) and fixation by cementation locally leads to black beachrock layers, which, when eroded, break into black pebbles (Strasser 1984). At site, where black beachrock is formed, abundant organic matter is furnished by marine plants (Cymodoceans), which are washed onto the beach during storms and then decay.

The large variety of parameters controlling beachrock cementation may explain the complex relationships and irregular distribution of the various types of cement. Superposition of different cements indicates changing of parameters through time and space. Early consolidation is dominated by marine (phreatic or vadose) cements precipitating at or close to the water table.

Beachrock situated above the water table undergoes freshwater diagenesis. Percolating rainwater locally dissolves unstable aragonite and high$\mathrm{Mg}$ calcite cements and precipitates low-Mg calcite. Percolation rate is high along root shafts or in the holes left after their decay. This leads to cemented protuberances at the bottom of the beachrock beds where the roots penetrated. Freshwater cementation seals primary porosity and hardens the beachrock significantly. Once exposed by erosion beachrock may superficially be further cemented by freshwater diagenesis or by carbonate precipitation from marine spray waters (Scoffin 1970).

Coexistence of various types of cement in beachrock is common (e.g. Stoddart and Cann
TABLE I

Minor and trace elements (ppm) of beachrock cements from Jaguaribe beach in Itamaracá island (Chaves 2000).

\begin{tabular}{c|c|c|c|c}
\hline & ITA-1 & ITA-2 & ITA-3 & ITA-4 \\
\hline $\mathrm{Na}$ & 5.39 & 4.45 & 5.39 & 5.39 \\
$\mathrm{~K}$ & 1.15 & 1.09 & 0.99 & 1.12 \\
$\mathrm{Ca}$ & 117 & 115 & 119 & 120 \\
$\mathrm{Sr}$ & 1.74 & 1.72 & 1.69 & 1.77 \\
$\mathrm{Mg}$ & 4.61 & 5.66 & 4.22 & 4.98 \\
$\mathrm{Fe}$ & 2.76 & 2.54 & 2.23 & 2.33 \\
$\mathrm{Mn}$ & 0.03 & 0.05 & 0.07 & 0.02 \\
$\mathrm{Al}$ & 1.20 & 1.46 & 0.97 & 1.05 \\
\hline
\end{tabular}

1965, Taylor and Illing 1969, Beier 1985, Strasser and Davaud 1986, Pirazzoli 1991). Fine-grained beach sediment has to be stabilized by burial in order to allow cementation. Roots and organic filaments may enhance stabilization. Blocks of beach conglomerate on the other hand can be heavy enough to resist constant dislocation by waves and cementation can well occur without previous burial (Montaggioni and Pirazzoli 1984 in Pirazzoli 1991). Sediment trapped in fissures of exposed beachrock or between pebbles of beach conglomerate will equally be incorporated. Fragments of beer bottles cemented into beachrock demonstrate that carbonate precipitation can be very rapid (Scoffin 1970).

\section{DIAGENETIC FACIES}

Beachrocks from the Jaguaribe beach look identical to any other in the littoral of Pernambuco. The inclusion of recent artifacts in many of these deposits demonstrates that they are continuously being formed today. Petrographically, rare aragonite cement micritized grains and micritic envelopes all of which are products of marine-phreatic diagenesis characterize this beachrock. Carbon and oxygen isotopic compositions of beachrock cement and uncemented sand are nearly identical; $\delta^{13} \mathrm{C}$ varies between $-2.0 \%$ and $+3.6 \%$ and $\delta^{18} \mathrm{O}$ between $-2.1 \%$ o to $+1.3 \%$. 
TABLE II

$\delta^{13} \mathrm{C}$ and $\delta^{18} \mathrm{O}$ values for beachrocks at Jaguaribe beach in Itamaracá Island (A) seawater, freshwater and interstitial water $(B)$ dissolved carbonate in the interstitial water; $(C)$ primary carbonates.

\begin{tabular}{|c|c|c|c|c|c|c|c|}
\hline \multicolumn{2}{|c|}{$\mathrm{A}$} & \multicolumn{3}{|c|}{ B } & \multicolumn{3}{|c|}{$\mathrm{C}$} \\
\hline $\begin{array}{c}\text { Water } \\
\text { samples }\end{array}$ & $\begin{array}{c}\delta^{18} \mathrm{O}_{\text {SMOW }} \\
(\%)\end{array}$ & $\begin{array}{c}\delta^{18} \mathrm{O}_{\text {SMOW }} \\
(\%)\end{array}$ & $\begin{array}{c}\delta^{18} \mathrm{O}_{\mathrm{PDB}} \\
(\%)\end{array}$ & $\begin{array}{c}\delta^{13} \mathrm{C}_{\mathrm{PDB}} \\
(\%)\end{array}$ & $\begin{array}{c}\text { Bioclastic } \\
\text { samples }\end{array}$ & $\begin{array}{c}\delta^{18} \mathrm{O}_{\mathrm{PDB}} \\
(\%)\end{array}$ & $\begin{array}{c}\delta^{13} \mathrm{C}_{\mathrm{PDB}} \\
(\%)\end{array}$ \\
\hline Ita-10 & -2.3 & -1.7 & -2.8 & +0.5 & Halimeda-1 & -2.5 & +0.2 \\
\hline Ita-2a & -2.5 & -0.6 & -3.1 & +0.6 & Halimeda-2 & -2.4 & +0.4 \\
\hline Ita-3a & -0.8 & -0.9 & -2.4 & -1.8 & Halimeda-3 & -2.3 & +1.7 \\
\hline Ita-4a & -1.5 & -1.8 & -1.9 & +0.7 & Halimeda-4 & -1.7 & +1.5 \\
\hline Ita-5a & -1.0 & -2.0 & -2.2 & +0.9 & Halimeda-5 & -2.0 & +2.1 \\
\hline Ita-6a & -2.4 & -0.8 & -1.8 & +1.5 & Halimeda-6 & -2.2 & +1.6 \\
\hline Ita-7* & +0.2 & - & - & - & Foram-1 & -2.7 & +0.5 \\
\hline Ita-8* & +0.5 & - & - & - & Lithothamium-1 & -1.9 & +1.3 \\
\hline Ita-9** & -2.8 & - & - & - & Bivalves-1 & -2.6 & +0.8 \\
\hline Ita-10** & -2.2 & - & - & - & Gastropods-1 & -2.4 & +0.3 \\
\hline
\end{tabular}

$\not{a}=$ interstitial water; $*=$ seawater; $* *=$ freshwater.

Carbon-isotope values for seawater, freshwater, interstitial water and primarily carbonates, of beachrock samples, show a general depletion in ${ }^{13} \mathrm{C}$ and ${ }^{18} \mathrm{O}$ relative to carbonates precipitated in equilibrium with seawater (Table II). The cement has a wider range of $\delta^{13} \mathrm{C}$ values than marine cements owing to the mixing of carbon from soil gas and dissolved carbonate sediment (Gross 1964). Block low-Mg calcite has ${ }^{13} \mathrm{C} /{ }^{12} \mathrm{C}$ ratios closest to those of marine cements suggesting that most carbon in precipitation fluids is derived from dissolution of metastable carbonates (e.g. present-day aragonite).

In these beachrocks, carbon-isotope ratios of whole-rock samples vary according to the proportion and isotopic composition of vadose and meteoric-phreatic cements. One whole-rock sample that is very enriched in ${ }^{12} \mathrm{C}$ suggests that some cement may be even lighter than those analyzed. Isotopic exchange during recrystallization of allochems may also contribute to ${ }^{12} \mathrm{C}$ enrichment of wholerock samples. The oxygen-isotope composition is also the result of diagenetic alteration by meteoric water and is controlled by $\delta^{18} \mathrm{O}$ of local rainfall, which is ${ }^{16} \mathrm{O}$-enriched relative to seawater (Allan and Matthews 1977).

Many beachrock allochems are partially to completely micritized. Micritization of grains most extensive at and in some cases limited to grain boundaries and results in development of a micritic rim or envelope around each grain. In some instances aragonitic cement is also micritized. Micritic cement is most strongly depleted in ${ }^{13} \mathrm{C}$ owing to increased organic activity.

There is an extensive evidence of organic activity. Small (10-20 $\mu \mathrm{m}$ in diameter) pits and tubes are abundant on beachrock surfaces. The exclusive presence of aragonitic cement in this rock suggest that lithification of beach sediments was predominantly a marine process. There is no petrographic evidence of meteoric interstitial influence in the precipitation of these beachrock cements and therefore no need to invoke seawater/interstitial mixing models to explain the cementation process. The isotopic composition also indicates precipitation from mixing sea/meteoric water. The rapid growth of aragonite crystals in beach sediments is readily accounted for in terms of seawater supersaturation and enhancement of conditions for precipitation by el- 
evated temperature evaporation and by fluctuations of the $\mathrm{pH}$ and $\mathrm{P}_{\mathrm{CO}_{2}}$ due to photosynthesis by algae living in and on the beach sand.

The algae are also responsible for micritization. The formation of micritic cement has long been attributed to the filling algal borings with minute crystals of secondary calcium carbonate (Bathurst 1966, Alexandersson 1972a, b).

This beachrock exhibits other assemblages of diagenetic features that include equant low-Mg calcite cement. Neomorphic transformation of aragonite cement and micritic low-Mg calcite. These contain abundant coarse crystals of equant low-Mg calcite cement. This sparry calcite completely fills intergranular voids in some cases thus greatly reducing porosity. The cement is partly originated from neomorphism of marine aragonitic cement and partly from direct precipitation in voids. Some calcite crystals adjacent to grain boundaries are oriented normal to the grain surface suggesting an originally fibrous texture; crystals in the center of the pores lack such orientation. Locally aragonite and block calcite cement coexist where neomorphism is incomplete.

The large size of spar crystals suggests precipitation from water-filled pores in a meteoric-phreatic environment (Land 1970). The distribution of spar cement is however patchy suggesting that precipitation of spar may have occurred in a microphreatic environment within vadose zone.

\section{CONCLUSIONS}

Several conclusions can be drawn from the study of contemporaneous beachrock on the Jaguaribe beach that may also be relevant for beachrock occurrences in other areas and other geological epochs:

(1) Beachrock forms through cementation of beach sediment, which generally has been stabilized by burial and in many cases also by filaments of algae and fungi. Primary sedimentary structures such as beach lamination, keystone vugs or root traces are commonly preserved.

(2) The phreatic/vadose interface at the groundwa- ter table offers geochemical and hydrodynamic conditions, which may be favorable for rapid precipitation of calcium carbonate. Microbiological activity may further stimulate cementation. Sediment above and below the active zone of cementation is not consolidated.

(3) Juxtaposition and superposition of various types of cement suggests that geochemical hydrodynamic and/or microbiological parameters changed through time and space. After a first stage of cementation leading to consolidation the beachrock may be further cemented in the vadose or phreatic zones or during exposure on the beach after erosion.

(4) Some particles can be relict and older than the final beach sediment. On the other hand cementation starts some time after sedimentation and may still go on after a long time. Total beachrock ages are therefore maximum ages for the beginning of cementation.

(5) As beachrock cementation probably starts at or close to the interstitial water its stratigraphic and topographic position may indicate the position of sea level at the time when cementation began.

(6) Coastal erosion and wave action however frequently undercut and break off beachrock beds and slabs of beachrock accumulate in the intertidal or shallow subtidal zones. Such fragments can be easily identified and used to approximately situate ancient sea levels.

The diagenetic cements of intertidal beachrock indicate sediment alteration in a variety of diagenetic environments. Relict aragonite-needle and micritic cement although rare indicate early diagenesis in a marine-phreatic environment. Blocky spar cements are characteristic of meteoric-phreatic diagenesis. This environment must have developed after early diagenesis in the marine-phreatic zones because neomorphic calcite replaces aragonite cement. The isotopic composition of the vadose fea- 
tures indicates that they were not precipitated from the same water, as the spar cement and. therefore the precipitation of spar cement was not contemporaneous with formation of the vadose features.

The following model for a progressive diagenetic sequence is proposed that pass through a cycle of local sea level changes.

The first diagenetic stage is typified by rock like that of the Holocene beachrock facies. Aragonite cement is evidence that marine-phreatic processes are dominant in the intertidal zone and that lithification occurs in this zone. The even coating of aragonite cement on sediment grains indicates that these crystals precipitated from pores filled with normal seawater. Colonization by algae and subsequent micritization of cement alter the newly lithified beachrock and result in the formation of well micritic cement around each grain.

As long as the beachrock occupies the intertidal zone growth of aragonite cement and organic activity will continue. New sand composed by corals fragments and other debris are cemented onto the beachrock surface. Large slabs of beachrock may be dislodged during marine transgression or storms and re-cemented into the intertidal deposits building ancient beachrocks lines. In this earliest stage of diagenesis, grazing intertidal organisms commonly erode beachrocks surface.

In the second stage a lowering of sea level moves the shoreline seaward leaving to that of their deposition. Here, the beachrock would most likely become buried by marine deposits (terraces) as evidenced by burial beach sediments. During this interval, the sediment is in contact with meteoric interstitial water. The meteoric water probably contained in a local phreatic environment within the vadose zone rather than an extensive interstitial lens as evidenced by the discontinuous distribution of the spar cements. The most important process in this stage is a neomorphic replacement of early aragonite cement by larger crystals of low-Mg calcite and precipitation of low-Mg calcite in pores. Reduction of porosity is greatest in this stage because low-Mg calcite completely fills some pores.
With further lowering of sea level the beachrock deposits are left even farther inland. In this environment interference by organic process by terrestrial plants (coconut trees). The extent of vadose and freshwater diagenetic features indicates that the more ancient beachrock had occupied an inland position for a relatively long time and, therefore, this beachrock was possibly deposited during the Holocene.

\section{ACKNOWLEDGMENTS}

This study is a part of N.S. Chaves' doctoral thesis and supported by grants from the Fundação de Amparo à Pesquisa do Estado de São Paulo (FAPESP). We want to thank Gilsa M. Santana and Vilma S. Bezerra for assistance with C- and O-isotope analyses at the LABISE, Federal University of Pernambuco. This is the contribution n. 228 of the NEGLABISE.

\section{RESUMO}

Os recifes de arenito holocênicos da praia de Jaguaribe, Pernambuco, Nordeste do Brasil, consistem de camadas de areias de praia dispostas de forma horizontal, cimentadas por carbonatos, com aproximadamente $40 \mathrm{~cm}$ de espessura. O cimento ocorre sob três tipos: a) calcítico, circundando os grãos siliciclásticos, b) micrítico, com uma franja acicular; e c) preenchendo os poros na forma de calcita criptocristalina. A cimentação, precoce, aconteceu ao nível freático abaixo da crista praial, onde condições geoquímicas, hidrodinâmicas e, talvez, microbiológicas favoreceram uma rápida precipitação de aragonita e/ou calcita magnesiana. $\delta^{13} \mathrm{C}$ varia de -1.8 a $+1.5 \%$ para carbonato dissolvido em água intersticial e de +0.2 a $+2.1 \%$ para componentes bioclásticos. $\delta^{18} \mathrm{O}$ varia de $-2.8 \mathrm{a}+0.5 \%$ na água do mar, água doce e intersticial. $\delta^{13} \mathrm{C}$ e feições diagenéticas sugerem que a cimentação ocorreu em água meteórica-vadosa e/ou marinha-freática, por perda de $\mathrm{CO}_{2}$ durante a evaporação da água intersticial. Localmente, cimento calcítico pouco magnesiano superimposto sugere influência de água doce subseqüente. A composição do cimento das camadas de recifes de arenito empilhadas verticalmente na praia de Jaguaribe mostra que a camada do topo do recife de are- 
nito é mais velha do a situada no presente nível freático. Isto implica em uma cimentação de cima para baixo, retratando provavelmente rebaixamento do nível do mar.

Palavras-chave: recife de arenito, diagênese recente, isótopos de $O$ e $C$, Holoceno.

\section{REFERENCES}

AleXANDERsson T. 1972a. Intragranular growth of marine aragonite and $\mathrm{Mg}$ calcite: evidence of precipitation from supersaturated seawater. J Sed Petrol 42: $441-460$

Alexandersson T. 1972b. Micritization of carbonate particles: Processes of precipitation and dissolution in modern shallow-marine sediments. Bull Geol Inst Univ Uppsala NS 3: 201-236.

Allan JR and Matthews RK. 1977. Carbon and oxygen isotopes as diagenetic and stratigraphic tools: Surface data, Barbados, West Indies. Geology 5: 16-20.

Baker PA, Gieskes JM ANd ENderfield H. 1982. Diagenesis of carbonates in deep-sea sediments - evidence from $\mathrm{Sr} / \mathrm{Ca}$ ratios and interstitial dissolved $\mathrm{Sr}^{+2}$ data. J Sed Petrol 52: 71-82.

BATHURST RGC. 1966. Boring algae: micrite envelopes and lithification of molluscan biosparites. J Geol 5: $15-32$.

BEIER JA. 1985. Diagenesis of Quaternary Bahamian beachrock: petrographic and isotopic evidence. J Sediment Petrol 55: 755-761.

Chaves NS. 1996. Beachrocks do Litoral Pernambucano: Estudo Sedimentológico e Análise de Isótopos Estáveis. Dissertação de Mestrado, Univertsidade Federal de Pernambuco, Recife, 80 p.

Chaves NS. 2000. Mecanismo de cimentação em sedimentos marinhos recentes, exemplo: beachrocks do litoral pernambucano. Tese de Doutorado, Universidade Estadual Paulista, Rio Claro, São Paulo, 194 p.

Chaves NS and Sial AN. 1999. Mixed oceanic and freshwater depositional conditions for beachrocks of NE Brazil: evidence from $\mathrm{C}$ and $\mathrm{O}$ isotopes. Int Geol Rev 40: 748-754.

Chaves NS, Sial AN and Coutinho PN. 1995. Aspectos geológicos e isotópicos de recife do litoral do Estado de Pernambuco. Anais V Cong Bras Geol e III Cong Geoq Países Língua Portuguesa, Niterói, $34 \mathrm{p}$.
Davies PJ AND KINSEY DW. 1973. Organic and inorganic factors in Recent beach rock formation. Heron Island. Great Barrier Reef. J Sediment Petrol 43: 59-81.

Given RK AND WiLKInSON B. 1985. Kinetic control of morphology. composition. and mineralogy of abiotic sedimentary carbonates. J Sediment Petrol 55: 109-119.

Gross MG. 1964. Variations in the ${ }^{18} \mathrm{O} /{ }^{16} \mathrm{O}$ and ${ }^{13} \mathrm{C} /{ }^{12} \mathrm{C}$ ratios of diagenetically altered limestones in the Bermuda Island. J Geology 72: 170-194.

HanoR JS. 1978. Precipitation of beachrock cements: mixing of marine and meteoric waters vs. $\mathrm{CO}_{2}$-degassing. J Sediment Petrol 48: 489-501.

Kitano Y and Hood DW. 1965. The influence of organic material on the polymorphic crystallization of calcium carbonate. Geochim Cosmochim Acta 29: 29-41.

LAND LS. 1970. Phreatic versus vadose meteoric diagenesis of limestones: Evidence from a fossil water table. Sedimentology 114: 175-184

Longman MW. 1980. Carbonate diagenetic textures from nearsurface diagenetic environments. Am Assoc Petrol Geol Bull 64: 461-487.

Pirazzoli PA. 1991. World Atlas of Holocene Sea-Level Changes. Ocean Ser, 58, Elsevier, Amsterdan, 300 p.

Scoffin TP. 1970. A conglomeratic beachrock in Bimini. Bahamas. Sediment Petrol J 40: 756-759.

StOdDART DR AND CANN JR. 1965. Nature and origin of beach rock. J Sediment Petrol 35: 243-247.

STRASSER A. 1984. Black-pebble occurrence and genesis in Holocene carbonate sediments (Florida Keys. Bahamas and Tunisia). J Sediment Petrol 54: 1097-1109.

Strasser A and Davaud E. 1986. Formation of Holocene limestone sequences by progradation. cementation and erosion: two examples from the Bahamas. J Sediment Petrol 56: 422-428.

SuEss E. 1970. Interaction of organic compounds with calcium carbonate. I. Association phenomena and geochemical implications. Geochim Cosmochim Acta 34: 157-168.

TAYLOR JCM AND ILLING LV. 1969. Holocene intertidal calcium carbonate cementation, Qatar, Persian Gulf. Sedimentology 12: 69-107. 